\title{
FULL - STRENGTH BUTT WELDS OF REINFORCING BARS BY THE PRESSURE - GAS PROCESS
}

\author{
I. C. Armstrong*
}

\section{Abstract}

Tho paper derinos sull-strongth but welded bar splicos and recognisos their suitability for rarthequato-resistant roinforced concroto structuros dotailod for ductility.

Aspects of the succesful use of the pressure-gas process on an "ight-slorey shear core building are reportid. Essential foaturos of a pressure-gas technique developed for making full-strength buit welds on sito are described. The significance of a band of decarburised steel occurring at the weld interface is discussed, and provisions for its control are indicated, The paper gives lest methods and criteria for quality contrul and acceptance purposes, with reference to a detailed Specification and "Statoment of Tuchnique and Equipment" under which the technique is now in principle accepted by the New Zealand Ministry of works.

Proving tests using the technique are reported, and a metallurgical report by $R$. M. Robb on the test welds, including micro-photographs, is appended. The paper concludes by indicating the practicability of making fullstrength butt welds of HY 60 bars by the pressure-gas process.

\section{Introduction}

Increasing use is being made of butt welded connections of reinforcing bars in earthquakeresistant concrete structures detailed for duct ility. Butt welds are particularly suitable for splicing large bars in columns, shear walls and foundations where serious congestion generally occurs.

It is the practice of the office of the Chief Structural Engineer, New Zealand Ministry of Works, to require full-strength butt welds. These are defined as having a strength which exceeds the actual strength (as distinct from specified strength) of the bars being joined, by a margin sufficient to permit full general elongation of the connected bars in tension. The welded connection thus develops the full. ultimate strength of the reinforcing bar and, therefore, considering the uncertainties of performance of a structure under extreme seismic conditions, achieves a fundamental aim of ductile detailing - the avoidance of premature, non-ductile failure.

The pressure-gas process is a relatively fast, economic technique for making full-strength butt welds of reinforcing bars on site. Under

* Design Engineer, NoZ. Ministry of Works, Wellington.

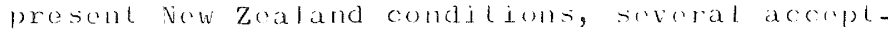
ablo wolding processes or jointing systems should proferably bo avaitablo, so that choice of method may be made where difficullios oxist (o. I imited access to bars or congestion or storl). The pressure-gas syslem provides one such procoss as an alternative lo present wolding mothods.

A previous reporl (1) described the pressuregas butt wolding process and roforred lo ils introduction into New Zoaland. The present paper refers to the succossful use of the mothod on the construction of an cight-storey shoar core building. The prosont welding technique and test methods and criteria for quality control are described. Dovelopment work and proving tests conducted to evaluate tho technique now being used are also reported. Detailed information is available in a specification(2), under which the process is now accepted in principle by the Ministry of Works, and in a detailed "Statement of Technique and Equipment" (3) covering the operation of the present technique.**

\section{Pressure-Gas Process}

In this process the square sawn bar end surfaces to be butt welded are freshly dressed and then closely butted together under hydraulic pressure in the clamp unit (Fig. 1). A multijet oxy-acetylene torch heats the bar ends while the reductive gases from the flame prevent access of air to the interface (Fig. 2). When the end surfaces first soften, gaps close under the pressure and the interface is sealed against entry of air. Further heating brings the joint interior to welding temperature $\left(1100^{\circ}-1200^{\circ} \mathrm{C}\right)$ when the torch is removed and full hydraulic pressure is reapplied to form an upset bulge at the joint (Fig. 4). The metal at the joint does not melt, and bonding takes place in the (softened) solid phase. During slow cooling in air, recrystallization in the weld zone and across the interface completes the bonding process. Time of heating is about 3 minutes (for $1 \frac{3}{8}$ in. diameter bar).

\section{Site Welding}

Successful Use on a Structure

The pressure-gas process has been used successfully to perform over 3,000 butt welds of reinforcing bars to NZS 1693 on the construction of an eight-storey reinforced concrete

* Available to Conference participants or by application to the Chief Structural Engineer, N.Z. Ministry of Works. 
Shear core building at Massey University. About 2,200 welds of No. 10 bars were made on the structure, the remaining 800 welds being of No. 9 and No. 8 bars. Butt welds of foundation beam reinforcement (horizontal bars and heavy stirrups) totalled 1,700 welds, while 1,300 welds connected mainly vertical bars in the shear core walls as construction progressed. A previous paper(1) included several photographs of this work

A modified bar clamp unit has resulted from the site welding work at Massey. The hydraulic ram, which normally locks into one end of the clamp unit to force the butting bar ends together, can now be transferred to the other end of the unit to open a working gap (about $1 \frac{1}{2}$ in.) between the bar ends. This permits long vertical bars to be clamped into the unit and a working gap opened using the ram; thus the bar ends can be given a final surface dressing by file or grinder immediately before they are butted together and welded. The modified bar clamp unit is shown in Figs. 1, 2 .

To establish the standard of welds produced at Massey, metallurgical examination was made of six welds. This showed the welds to be consistent and metallurgically of a high standard. Over the central area of the weld plane (corresponding to the nominal bar area) the interface is discernible only at high magnification; bonding and grain development across the interface are excellent, and oxide inclusions insignificant. A micrograph is shown in Fig。 3 .

\section{Filing/Grinding: Moisture: Wind}

Although it is preferable to perform the important bar end surface dressing operation by hand filing, the less tedious use of light griding has been successful, but must be performed carefully to avoid oxide formation due to heating of the metal.

It has been clearly established in practice that departure from specification as to dryness of the bar ends will produce defective welds. Moisture on the end surfaces must be removed by gentle heating, and the surfaces subsequently re-freshened by dressing immediately before welding; this has been made practical by the bar clamp modification, which permits the early resumption of site welding after rain.

It has also been found on site and in recent tests that wind velocities greater than about 5 - 10 miles per hour tend to disturb the torch flame, which can result in faulty welds because (a) the blanket of reducing gases enveloping the joint is breached and rendered ineffective in excluding air from the surfaces, and (b) heat is lost and the bar is unevenly heated. Since wind is inevitable on multistorey construction in this country, protection of site work must be provided.

\section{Decarburisation: 'Flat Fracture"}

During trial pressure-gas welds of bars rolled from an experimental low-carbon, niobiumrefined steel (having tensile strength similar to that of HY60 bars to NZS 1879), bend test specimens consistently fractured at the weld interface, showing typical "flat fracture" surface (light grey, flat, smooth surface) over parts of the break. Some flat fracture surface shows on one side of specimen A20, Fig. 6.

Metallurgical examination showed that in flat fracture areas the fracture path lay through a fine band of decarburised steel (i.e. ferrite, $\mathrm{Fe}$ ) containing some minor oxida inclusions. A crack in the ferrite band during the bend test can act as the initiator of a complete brittle fracture (reinforcing bars are generally "notchbrittle at room temperatures).

Decarburisation at the interface is believed to result from interaction between oxide layers on the butting surfaces and carbon in the steel at welding temperatures. The fine ferrite band is usually an annulus, mostly in the outer (upset) area of the finished weld; but if welding is sub-standard the band may be thicker (hence weak), extend over much of the interface area, and contain significant amounts of oxide. It appears inevitable at present that some decarburisation will result when welding structural or intermediate grade bars.

The thickness (metallurgically) and extent of the decarburised band clearly determines the standard and strength of the weld. A thin ferrite band even if extensive may be $\overline{q u i t e}$ strong when the total weld area (twice the bar area) through the upset is considered. A thick band might be satisfactory only if limited in extent to the extreme outer edges of the weld - but this result can not consistently be assured in practice.

At this stage is is considered prudent to require that in the finished weld any decarburised band of ferrite be consistently thin (metallurgically; refer to the Appendix) and be generally limited in extent to the upset area of the weld. Thus the central interface area should be free of decarburisation, permitting a metallurgically high standard of bonding across the interface to be achieved.

\section{Present Technique}

Considerable development effort was directed towards a technique(3) which would consist ently produce welds meeting the above requirement as to the decarburised band of ferrite. Decarburisation is controlled by minimising the formation of oxide on the butting surfaces, and is further improved by devising favourable conditions (within practical limitations) of temperature and pressure application to assist breaking up of the ferrite band during upsetting.

\section{Minimising Oxide Formation}

A close tolerance $(0.015$ in, i.e. $1 / 64$ in.) has been set upon face fit of the square sawn butting surfaces (fig。1), which must be freshly dressed immediately before welding commences (using the two-way bar clamp movement). The technique requires that the torch flame and its protective envelope of reducing gases be direct ed constantly at the line of the butting faces throughout the initial heating phase (Fig. 2), thus providing maximum protection against access of air to the heated metal of the end surfaces. This requirement also achieves closure and sealing of the softened joint in the shortest possible time, and thus further minimises oxide formation on the heated butting surfaces, Joint closure is taken as complete when in. movement together of the bar ends is indicated on the bar clamp movement pointer. 


\section{Main Heating to Temperature}

Following closure of the joint, the main heating phase applies heat to the whole weld zone within a distance equal to half the bar diameter on each side of the interface, while the hydraulic pressure is allowed to fall away. A given quantity of heat is applied to the joint, by means of specified gas settings and total heating time, to ensure that the centre of the interface reaches the desired temperature (about $1150^{\circ}-1200^{\circ} \mathrm{C}$ ). The maximum temperature on the bar axis can be measured by welding a short test bar which is drilled axially with a $\frac{1}{4}$ ino dia. hole to within in. of the butting end surface, using a thermocouple and pyrometer instrument for obtaining the temperature.

\section{Forming Upset}

Application of the upsetting pressure aims to break up decarburised layers and any oxides at the interface while forming the upset. This process appears to be less effective when temperature variation exists across the weld face (i.e. between bar surface and axis), probably because the upsetting force is then transmitted largely through the stiffer central area of the bar section which is at a lower temperature. The torch therefore must be extinguished before upsetting commences, to allow some cooling of the bar surface to result in a more uniform temperature over the butting face. The upsetting force is thus spread more widly over the contact area, and this appears to improve the fragmentation and dispersal of the fine ferrite band.

This process is also assisted by increase in finished upset size. The diameter of finished upset bulge (excluding bar deformations) at the weld plane is set at a minimum of 1.50 times nominal bar diameter. Upset size is controlled closely by observing movement together of the bar ends indicated by a pointer moving over a fixed scale (Fig. 1).

\section{Slow Cooling in Air : Recrystallisation}

The bonding process involves a solid phase transformation which promotes recrystallisation (grain growth) in the weld zone and across the weld interface during slow cooling in air to a temperature of about $720^{\circ} \mathrm{C}$. The technique(3) therefore requires the final upsetting pressure to be maintained for a minimum cooling period of five minutes after the torch is extinguished (Fig. 4). No quenching or other rapid cooling of the weld zone is permitted. Completed welds are seen in Figs. 5 and 6.

\section{Methods of Test}

Test methods and criteria have been developed for pressure-gas butt welds of reinforcing bars $(2)$. The importance attached to control of the decarburised band of ferrite containing oxide inclusions, which shows as "flat fracture" surface (light grey, flat, smooth surface) where the break path of a test bar passes through the band, prompted a review of the previously used method of bend testing pressure-gas butt welds.

The bend test is of limited value since much of the weld area (including upset) is removed by machining to a uniform section, which has a practical maximum diameter of about (nominal diameter minus $\frac{1}{4}$ in.). A nick-break test was therefore devised for checking the degree of decarburisation at the weld interface by examining the break surface for "flat fracture" and reporting the angle of bend at failure. This test has proved very useful. (Figs. 6 \& 7). Specimen A20, Fig. 6, shows flat fracture surface in upset area on one side.

The standard tensile test of a machined proportional rouni test specimen has a limited cross-section area similar to that of the bend test. It is nevertheless useful as a check on the tensile strength of the inner weld area (diameter about 3/16 in. less than nominal bar diameter), and also checks ductility in tension (elongation) of the welded specimen. A reducedsection tensile test has been introduced, having a machined reduced section (diameter $1 / 16$ in. less than nominal diameter) over the upset length only. This specimen fractures in tension at or adjacent to the weld interface and thus measures the ultimate tensile stress sustained by the reduced section containing the weld plane at its mid-length. In checking that a full-strength butt weld has been produced, these tensile tests do not rely on additional strength due to the increased cross-section area at the upset interface (Fig. 5).

Site procedure test requirements include the above tests, together with measurement by thermocouple of the temperature attained on the bar axis close to the weld interface during actual welding, and (if necessary) metallurgical examination of completed welds. Acceptance testing of production welds is based principally on the nick-break and reduced-section tensile tests, with othar tests being applied when considered necessary.

\section{Weld Tests, of No. 11 Bars, HY45 Steel}

A series of 47 pressure-gas welds of No. 11 deformed bars of HY 45 steel (a special N.Z. Ministry of Works specification) were subjected to extensive proving tests. The bars used were rolled by Pacific steel Ltd. from four different casts, of similar composition and properties by mill certificate having average values as follows: Carbon $0.24 \%$, Manganese $0.73 \%$, Silicon $0.36 \%$, Phosphorus $0.021 \%$, Sulphur $0.029 \%$, Yield stress $52,3001 \mathrm{~b} / \mathrm{sq}$.in., U1timate tensile stress $79,600 \mathrm{Ib} / \mathrm{sq}$. in. Elongation $20 \%$.

All test welds were made in four groups by the same operator using the standard procedure for No. 11 bars, with readings as follows: Metering gauge for flame setting $8 \mathrm{lb} / \mathrm{sq}$.in.; Heating time to closure, $1 \mathrm{~m} .25 \mathrm{sec}$; Total heating time 3 min. 00 sec.; Hydraulic pressure, $5,000-6,000 \mathrm{lb} / \mathrm{sq}$. in. on gauge $(6,200=7,500$ $\mathrm{lb} / \mathrm{sq}$. in. on nominal bar area); Movement of moving jaw towards fixed jaw (pointer on scale): $\frac{7}{8} "$ at closure, total $1 "-1 \frac{1}{8} "$ at end of upset.

\section{Tensile Tests}

These were made as follows, and a typical set of test results is given in Table 1. Specimens are shown in Fig. 5.

4 standard machined ( $1 \frac{1}{8}$ in. dia.) tensile tests.

4 standard tensile tests of identical but unwelded specimens.

4 tensile tests with upset machined off. 
4 reduced-section tensile tests, machined to $1 \frac{1}{4}$ in. dia. at the weld.

4 tensile tests with upset remaining intact.

\section{SEE TABLE 1 .}

Bend Tests

Ten welds were subjected to bend tests, all tests being successful. Four specimens were machined to a uniform section ( $1 \frac{1}{\mathrm{~g}}$ in。dia.) and bent round a former of $4 \frac{1}{2}$ in. diameter ( $4 D$ )。 Three specimens with upset remaining intact on the welded deformed bar (no machining) were bent tightly with a concentrated load acting at the upset. The remaining three tests are not significant. Typical bend test specimens are shown in Fig. 6 。

\section{Nick-Break Tests}

Twelve welds each had parallel saw-cuts made on the line of the weld interface leaving $1 \frac{1}{8}$ in. depth of material between parallel cuts, and were nick-break tested after the compression "flanges" had baen ground off.

The angle of bend at failure (i.e. when the tension crack has started to open visibly) is regarded as significant in this test. Values for the twelve specimens averaged $50^{\circ}$ (range $35^{\circ}$ to $80^{\circ}$ ).

Ten specimens resulted in break surfaces having no significant areas of "flat fracture" and of these, the specimens shown in Figs. $6 \&$ 7 are typical. Specimen A.15 (not shown) was satisfactory since the central interface area (equal to the nominal bar cross-section) was free of flat fracture, but it did show extensive flat fracture in the upset areas.

Specimen A. 14 (Figs。 $8 \& 9$ ) showed extensive areas of flat fracture and failed the test, but is worthy of comment. This specimen bent to $40^{\circ}-45^{\circ}$ with a fracture opening in a ductile manner, not at the interface, but through the parent bar. Fallure then occurred by separation through the ferrite band at the interface as shown. The ferrite band must presumably be thin, even though extensive in area in this case; since it was strong enough to sustain the stresses which opened the fracture in the parent metal.

\section{Temperature Measurement Tests}

Five test welds were made on short bars, with one bar in each weld drilled axially with a $\frac{1}{4}$ in. dia. hole to $\frac{1}{6} "$ from the butting surface and a thermocouple tip inserted. Four of these welds, using the same calibrated pyrometer instrument, gave maximum temperatures on the bar axis at the weld of $1175^{\circ}-1200^{\circ} \mathrm{C}$. The fifth test weld, using a different instrument, gave a confirming maximum temperature of $1200^{\circ} \mathrm{C}$. (The bar surface was, of course, near melting temperature).

This temperature is at the upper end of the acceptable range; however at the present time the procedure aims to achieve this temperature in the workshop in order to leave a margin for losses of heat during site work.

\section{Metallurgical Examination}

Four test welds, together with one special weld made at the same time as the test seriob but on No. 11 bars to NZS 1693 (specified yield point 40,000 1b/sq.in.) were submitted for examination by a consultant metallurgist familiar with the process.

The consultant's report is reproduced in full in the Appendix.

\section{Conclusion}

The pressure-gas butt welding techniquo recently developed has been proven by test to produce full-strength butt welds of reinforcing bars of the required standard. For site welding, the method is considered to be economic and speedy in operation, and will give consistent results provided the procedures for bar end preparation and welding are followed carefully.

The paper refers to methods of test and criteria for acceptance of pressure-gas butt welds, and describes the procedures devised to effectively limit the occurrence at the weld interface of a fine band of decarburised steel (Ferrite) containing some oxide particles, to a degree which is acceptable in the finished weld. A metallurgist's report includes microm graphs showing the extent of this decarburisation and assesses the standard of weld from a specialist viewpoint.

Due to the large heat input, cooling in air is relatively slow and (unlike manual arc welding) chilling of the steel does not occur. High strength hot-rolled bars should therefore be readily weldable by the pressure-gas process, and a few successful test welds of HY60 bars to NZS 1879 containing $0.34 \%$ carbon (by mill certificate) appear to confirm this. These few test welds of HY60 bars indicate a possibility (not yet confirmed) that formation of the decarburised band may be reduced or perhaps eliminated in this grade of steel due to the higher carbon content. Thus pressure-gas welding of HY60 grade bars appears practical, and future work will aim to establish a technique for welding these bars.

\section{Acknowledgements}

The development work and tests reported were carried out in the workshop of N.Z. Industrial Gases Ltd., whose continued willing co-operation in undertaking the work and sharing in the costs is gratefully acknowledged. The author is specially appreciative of the major contributions of $\mathrm{Mr}$. T. S. Prichard, Workshop Manager who directed the work and prepared the original "Statement of Technique and Equipment" and of $\mathrm{Mr}$. T. W. Watt whose many ideas and efforts in carrying out approximately 400 welds played a key role in the project.

The author is indebted to Mr. O. A. Glogau, Chief Structural Engineer and Mr. G. H. F. McKenzie, Assistant Chief Structural Engineer, for their interest, advice and guidance as the work progressed; and to Mr. R. M. Robb, (Metallurgical Consultant (whose micrograph appears as Fig. 3) ) for valuable advice and assistance. Special thanks are also due to Mr. Glogau for helpful comments and support in the preparation of this paper.

The author wishes to thank Mr. J. H. Macky, Commissioner of Works, for permission to present this paper. 
274

\section{References}

(1) Armstroners, L. C. and Page, W. J, : "ProssureGas l3ut Wolding of Roinfurcing Bars". Bullotin of the N.Z. Suciety for Earthquake

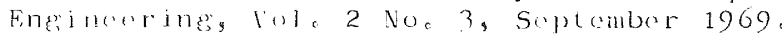

(2) "Pressurn-Gas Bute Welding wf Roinfereing Bars". Architoctural Stanclard Specification, N.Z. Ministry of Works, January. $1971 . *$

(3) "Prosisuru-Gas Butl Wolding of Roinforcing 13ars: Stalement of Tochmique and Fquipmont". N.Z. Ministry or Works, Fobruary

\section{Appendix}

\section{Metallurgical Report on Pressure-Gas Welds}

\section{R. M. Rublo**}

Five samples of prositure kas wolds were solected for complote metal lographic oxamination. Samplos or H45 steol numbered A31, A32, A45 and 447 wore solocted along with a ratiplo of NZSS $1693 ; t o r l$ No. A53. Longitudinal sections tlirough theso welds were surface ground and one diamelir face was used for macrographic examination while the other face was used for metallographic examination. All samplos wero polished and elched in Nital and the plane of the weld was examined. The major differences found in this examination wero in the maximum temperature reachod at the surface of the material and this was reflected in the distanco from the original bar surface at which the plane of weld could be identified. For this reason only typical photographs are included in this report.

On previous occasions when metallographic examination of pressure gas welding samplos has been undertaken a distinct ferrite band containing non-metallic inclusions was observed at the original weld plane and fracture of the samples in nick break tests had occurred through this band.

Sample No. A 45 was chosen to illustrate what is considered to be a good pressure gas weld and this is shown in Figures A1 and A2. In Figure A1 the flow pattern of the upset area can be distinguished and the grain coarsening, due to the high surface temperature, is obvious. In Figure A2 it is noticed that the original weld plane is distinguishable by virtue of grain boundaries not merging completely and fine non-metallic inclusions, but this plane gradually becomes indiscernible and the fine non-metallic inclusions can be seen passing through a complete pearlite grain. As this weld plane has disappeared at a distance of only 0.008 inches, from the original bar surface, the full strength of the bar will be developed over the remaining homogeneous material.

Figures $A 3$ and $A 4$ show similar areas of Sample No. A47 and it is obvious that this sample has been overheated and burnt on the original bar surface. However, this overheat ing does not penetrate far into the bar and

* Available by application to the Chief Structural Engineer, N.Z. Ministry of Works.

* Managing Director, Metlabs (N.Z.) Lld., Consulting Metallurgists. it is cousichorod that siatisfactor phy-irit propertios would be obtainod reon lhi also. This arorhoatitug is mole cluarly illus.

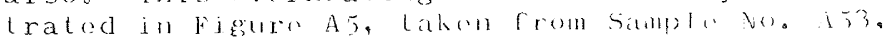
al a dislanco of 0.010 inches fron the surfare.

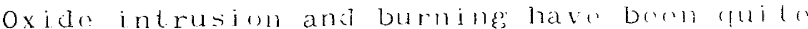
sevoro on this sampla.

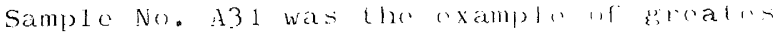
depte of ponctralion of tho of

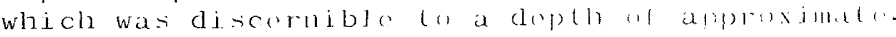

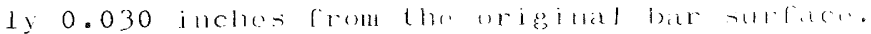
Figures $A 6$, A? and $A 8$ show this pland lo a doplh of 0.024 inches and figurs 9 shens lhe body of the bar at a depth of 0 . jo incles fiem the originat surface, Al though this bat i

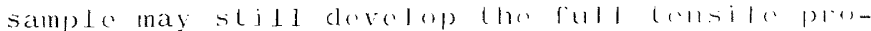

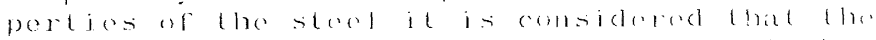

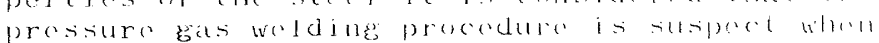
tho wole plande is cloarly cliscomible in this minner. Samplo No. A32 011 ho other haticl is illustraled in Figuros 410 and A11; il will be seon lad the weld plane is discomibl: onfy with dirficully, alld has virtually disappeared at a depth of 0.024 inclues frem the sur race.

This rxamination has shown lhat tho pressure gas welding lochnique is melallurgically sound for this malerial and hat lhe points of fine control over the healing cyclo are of major importance. The rate of hoat imput nust be balanesd with the ralo of hod transfor such that tho completo soction roaches wolding tomperaturo quickly lo provont oxidation of the mating surfaces, but slowly onough that severe burning dors not occur。 
TABLE $1:$ TENSILE TESTS

\begin{tabular}{|c|c|c|c|c|}
\hline $\begin{array}{c}\text { Specimen } \\
\text { (From left to right in Fig. } \\
5 \text { ) }\end{array}$ & $\begin{array}{c}\text { Yield Stress } \\
1 \mathrm{~b} / \mathrm{sq} \cdot \mathrm{in}\end{array}$ & $\begin{array}{c}\text { Ultimate Tensile } \\
\text { Stress } \\
1 \mathrm{~b} / \mathrm{sa} \cdot \text { in }\end{array}$ & $\underset{\%}{\text { Elongation }}$ & $\begin{array}{l}\text { Refer } \\
\text { to } \\
\text { Note }\end{array}$ \\
\hline Standard Tensile (unwelded) & 47,000 & 84,000 & 28 & $(1)$ \\
\hline Standard Tensile (welded) & 51,000 & 84,000 & 22 & (1) \\
\hline Tensile, upset removed & 46,000 & 77,000 & - & $(2)$ \\
\hline Reduced-section tensile & - & 85,000 & - & (1) \\
\hline Tensile, upset intact & 46,000 & 76,000 & - & (2) \\
\hline
\end{tabular}

Note (1): Stresses based on machined section.

Note (2): Stresses based on nominal bar area. 


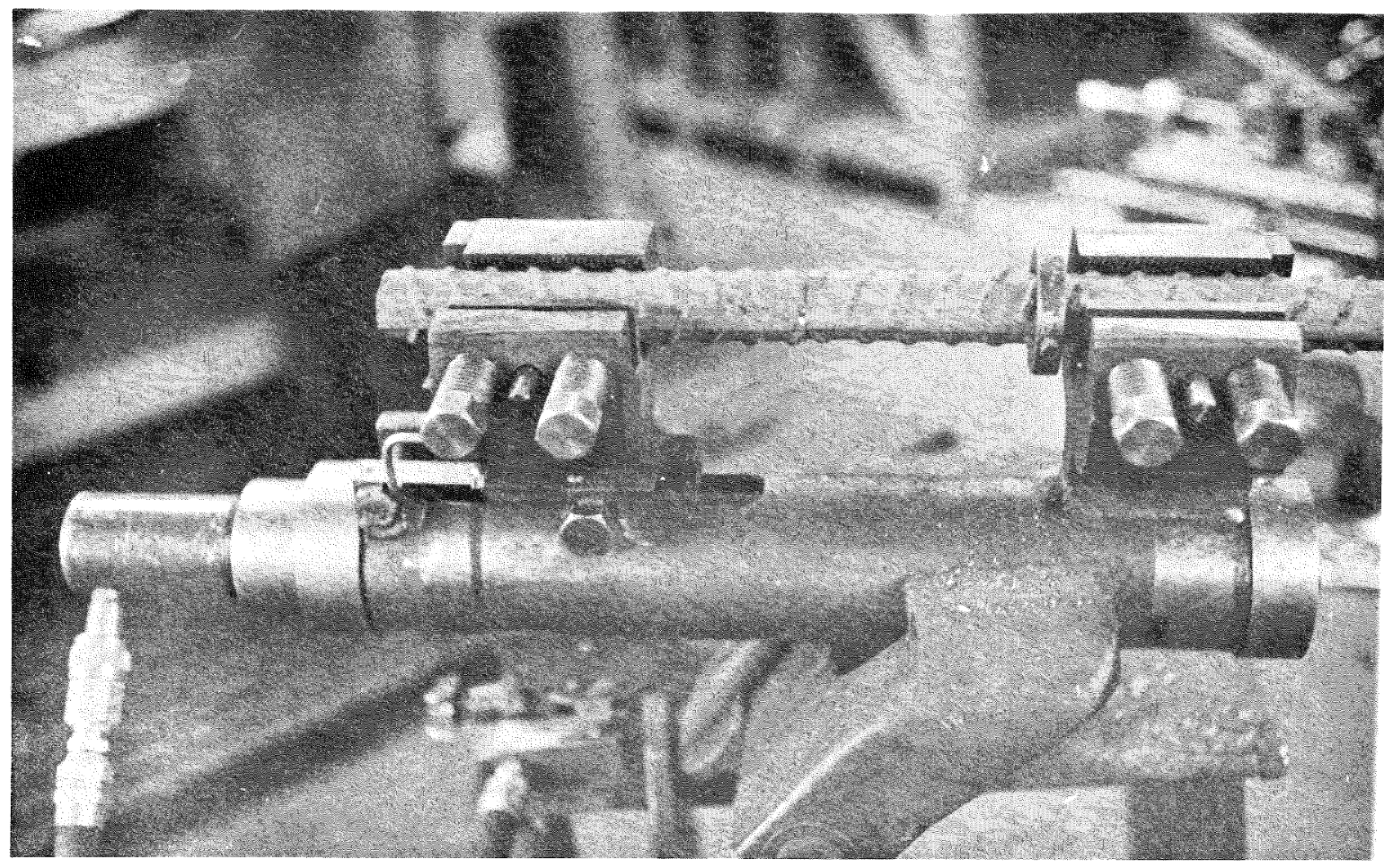

Figure 1

Bar ends butted in clamp unit ready for welding. Note close fit of end faces.

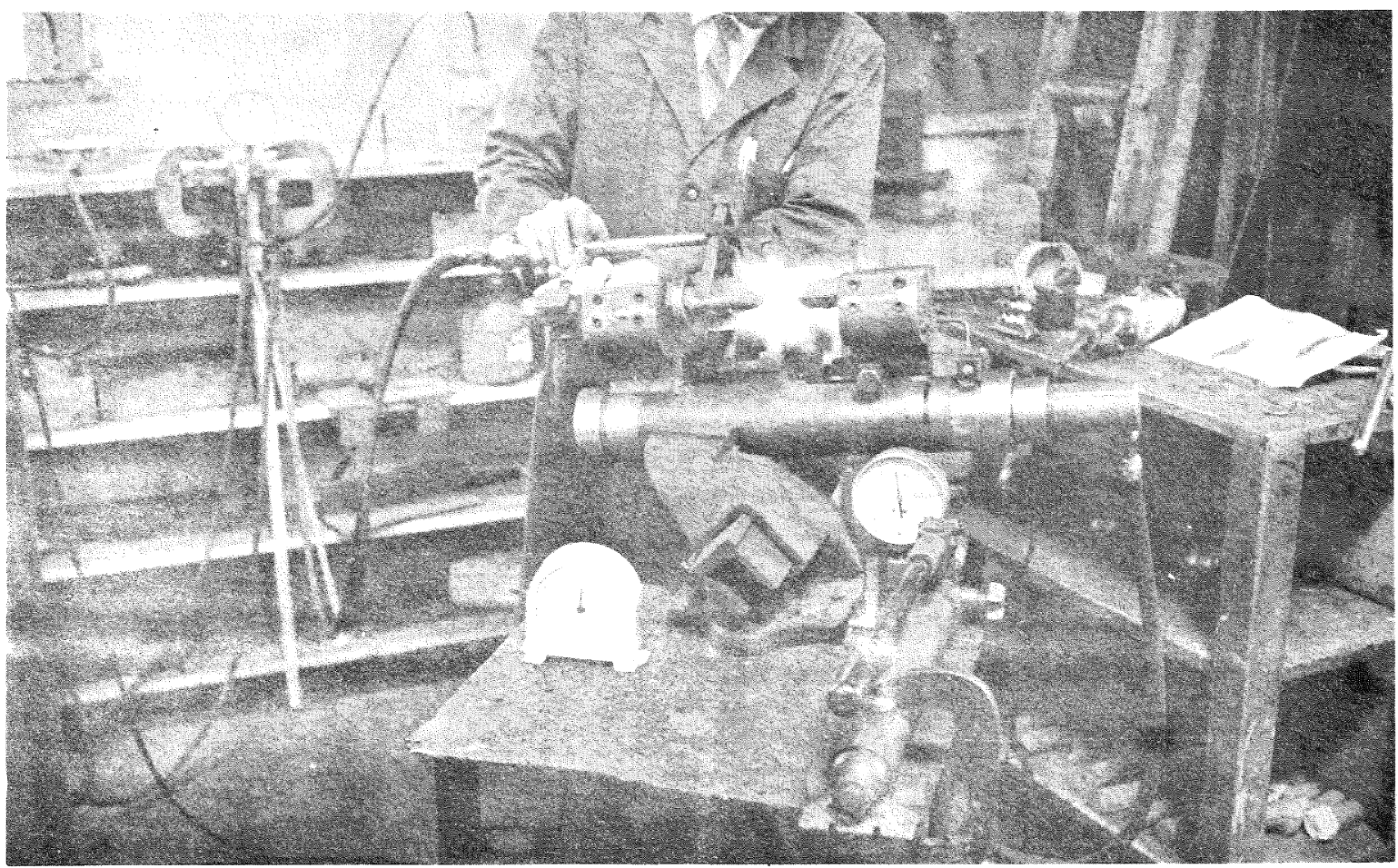

Figure 2

Initial heating phase, with hydraulic pressure applied. 


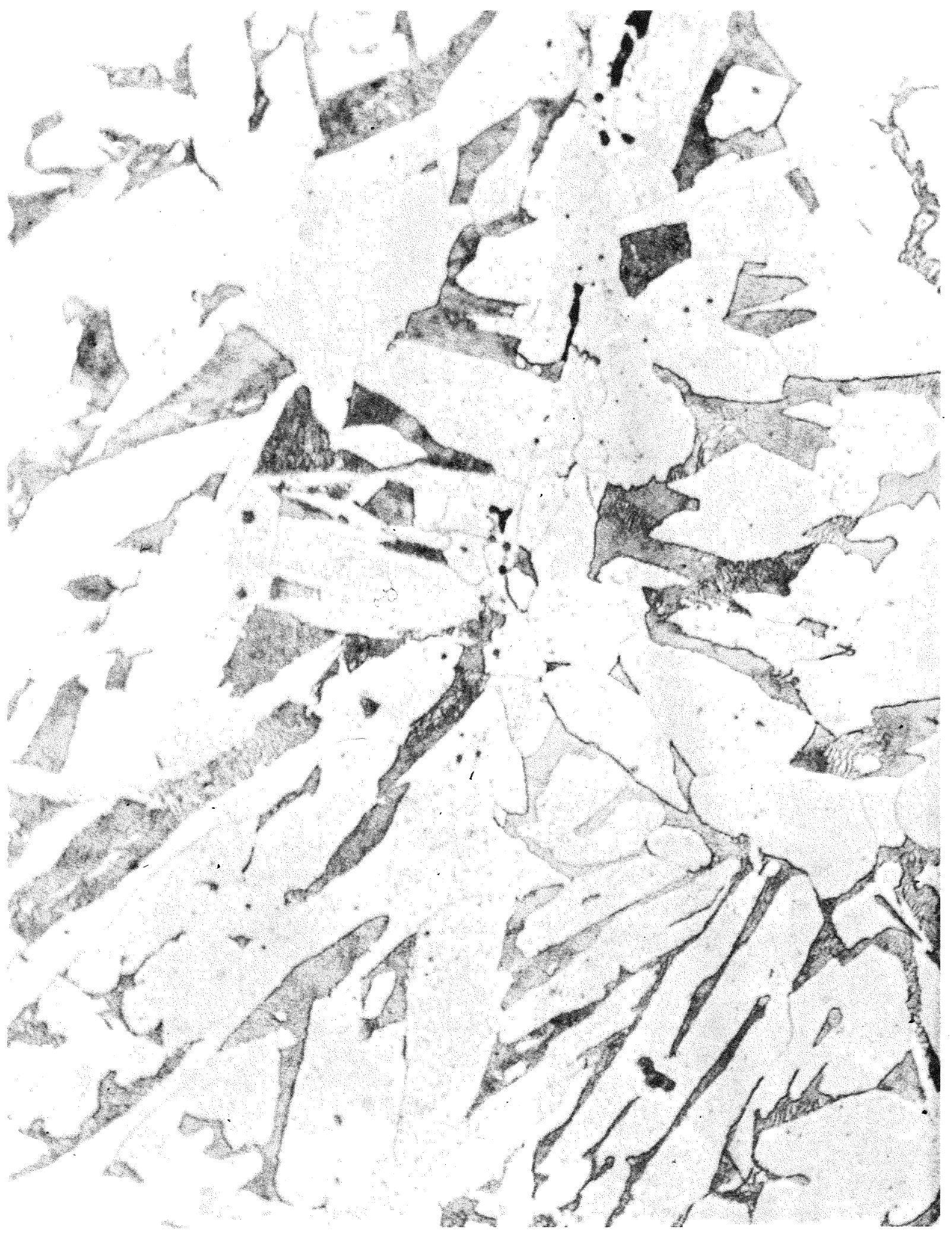




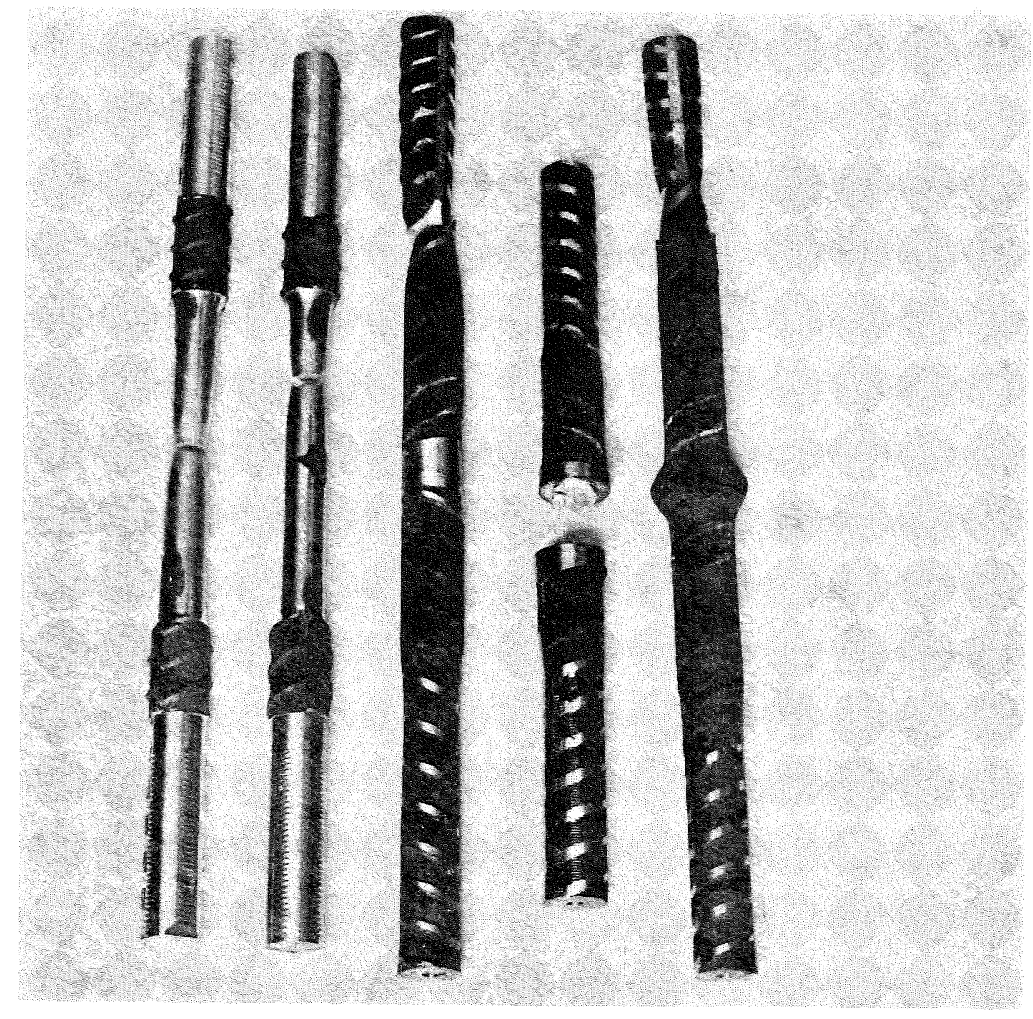

Figure 5

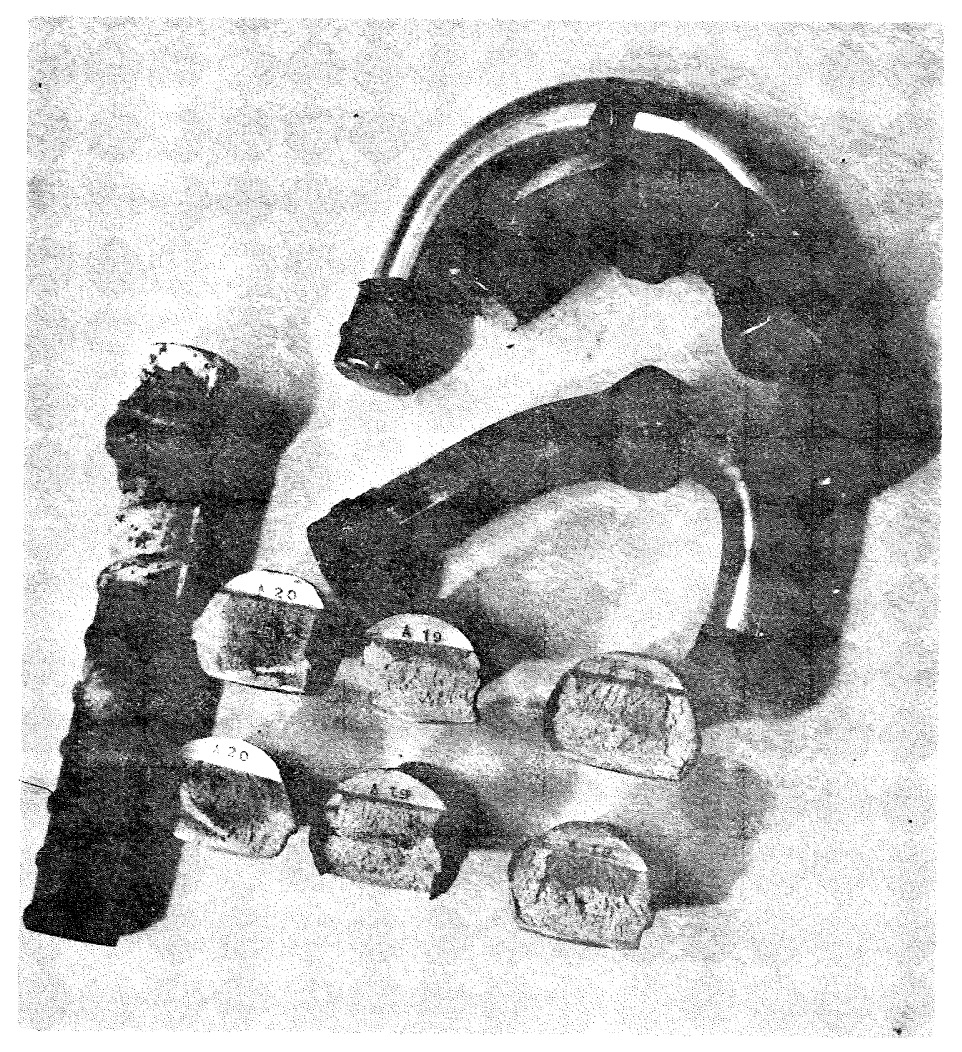




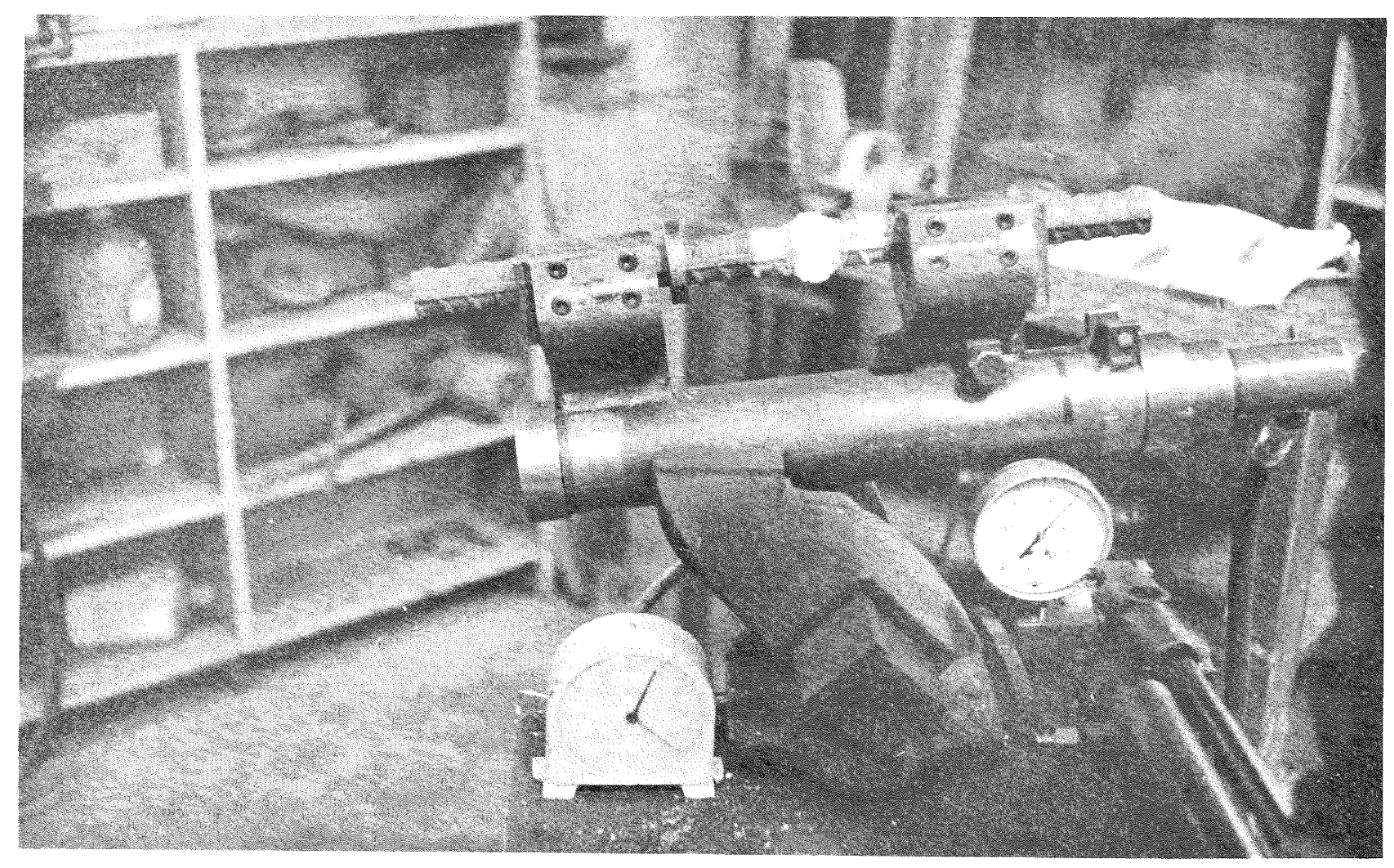

Figure 4
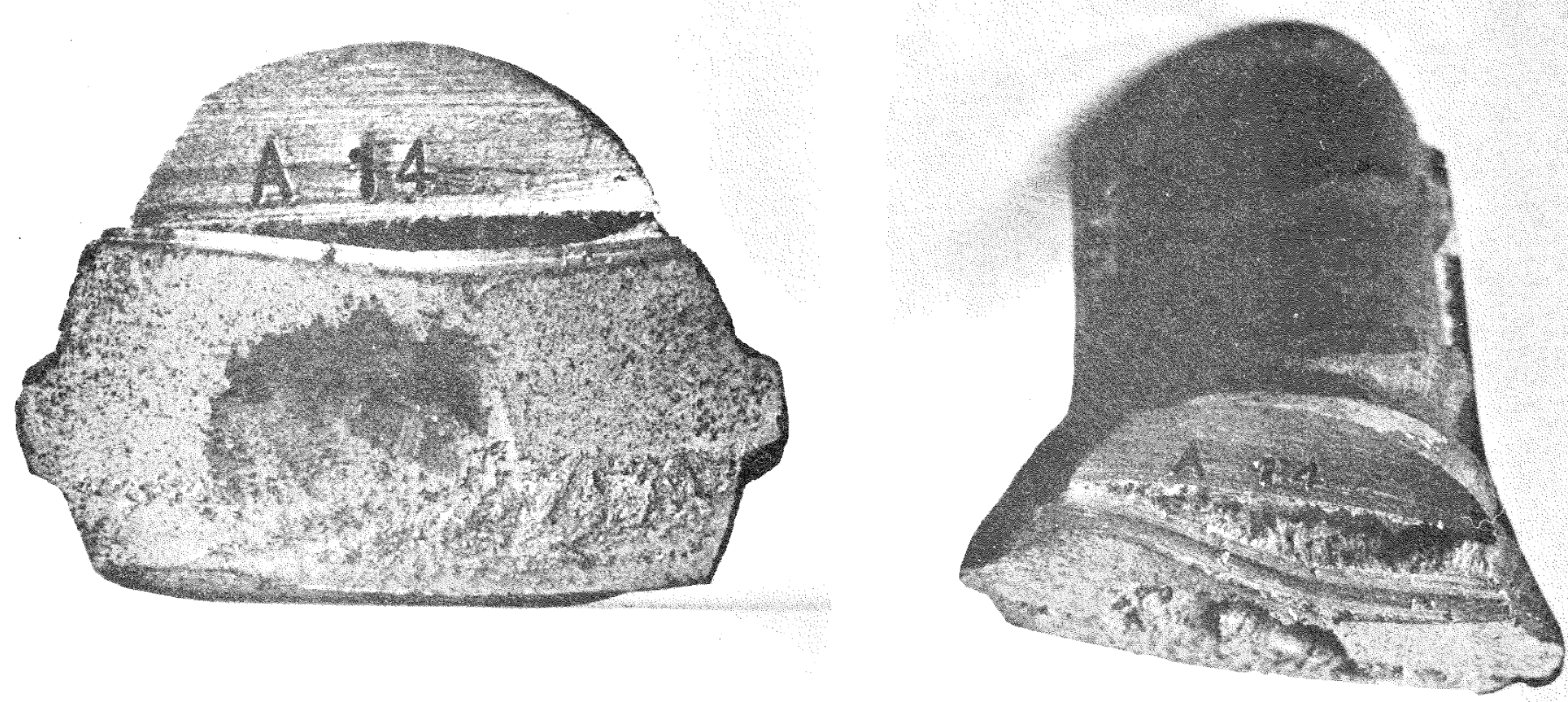


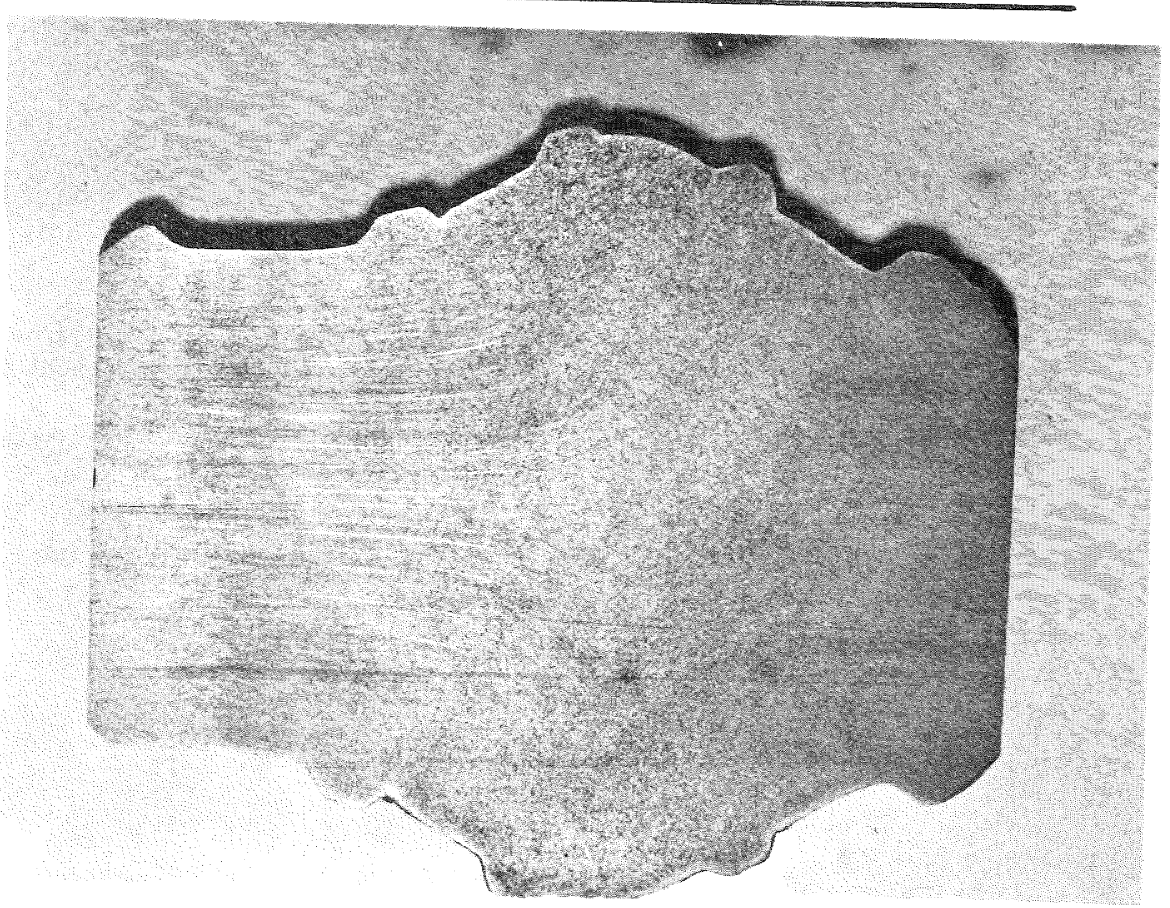

Figure $A 1$

Macro of Sample A45 showing upset flow and coarsened grain size.

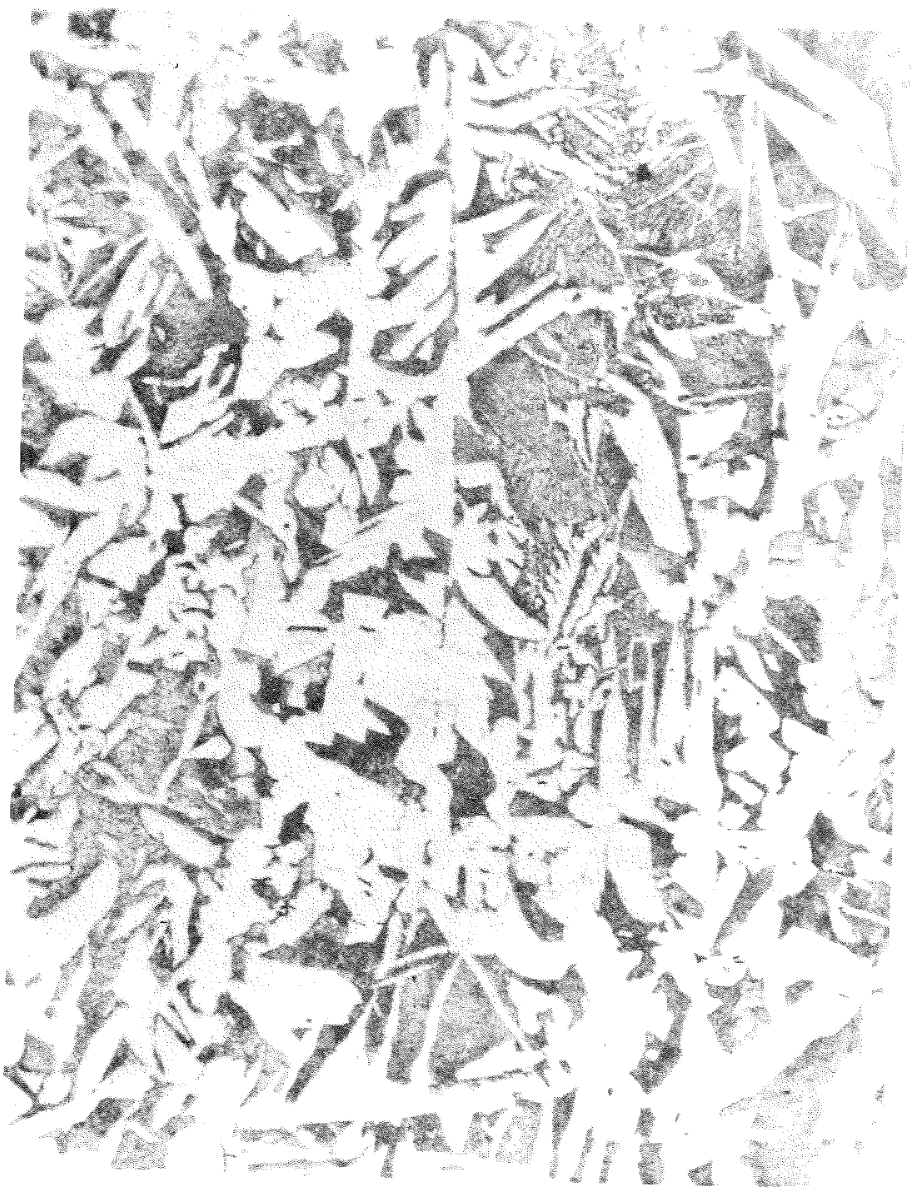

Figure A2

Micro of Sample A 450.008 inches from surface showing weld line breaking up $t$ $s_{m a l l}$ inclusions in complete pearlite grain.

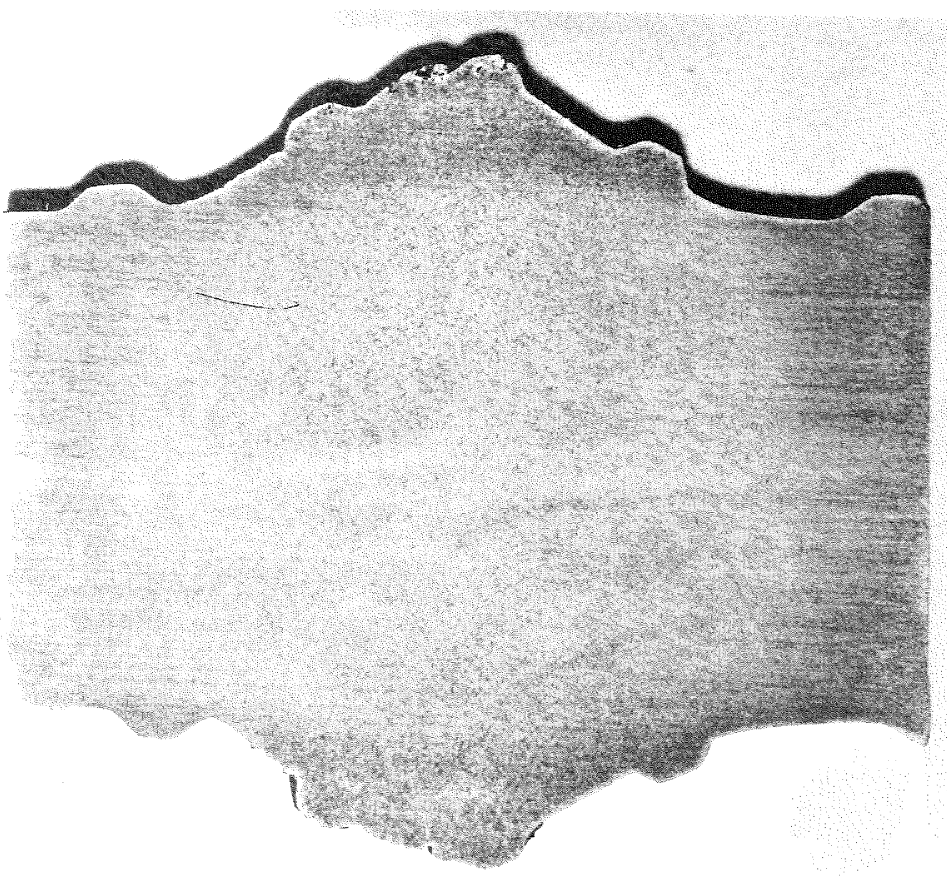

Figure A3

Macro of Sample A 47 showing upset flow, coarsened grain size, and burning at surface.

$x \quad 1.6$ 
PRESSURE GAS WELDING - HY45 at N.Z.I.G.
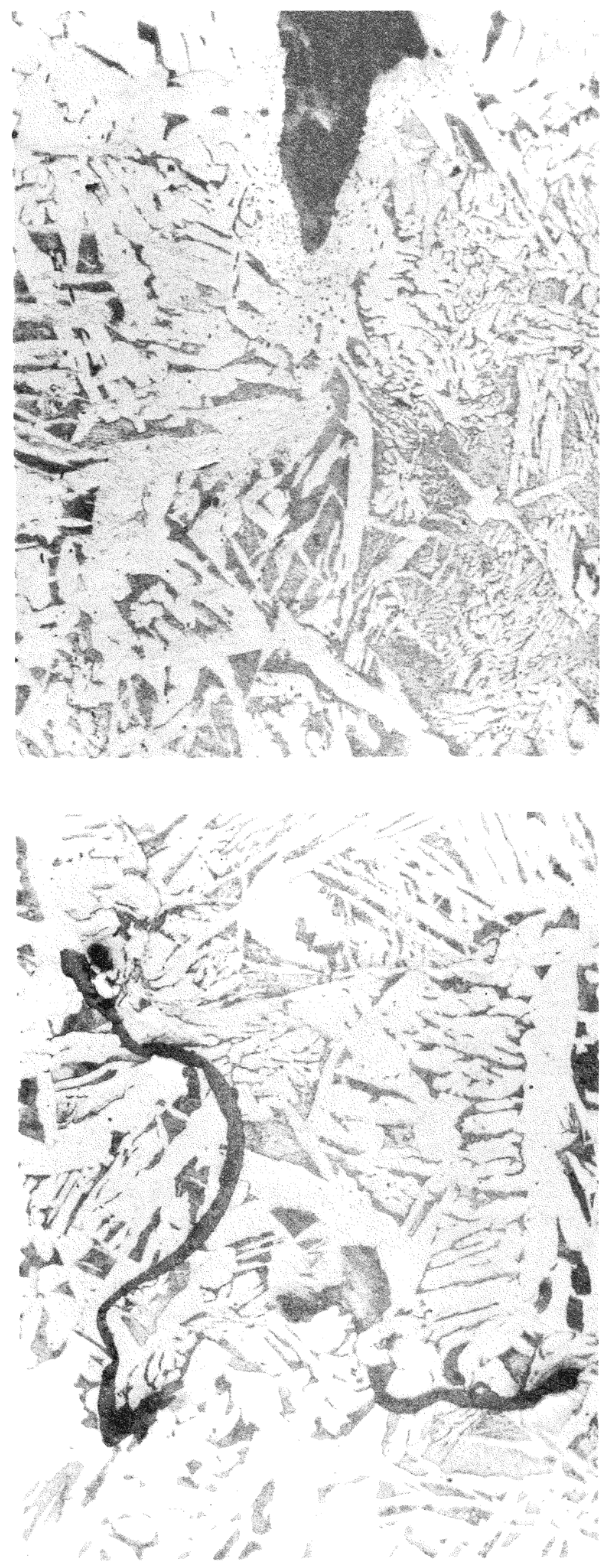

Figure A4

Micro of Sample A 470.008 inches from surface showing oxide intrusion of burning but no indication of weld plane. $x \quad 250$
Figure A5

Micro of Sample A53 0.010 inches from surface showing severe oxide film from burning of steel. This sample is NZSS 1693 steel. 

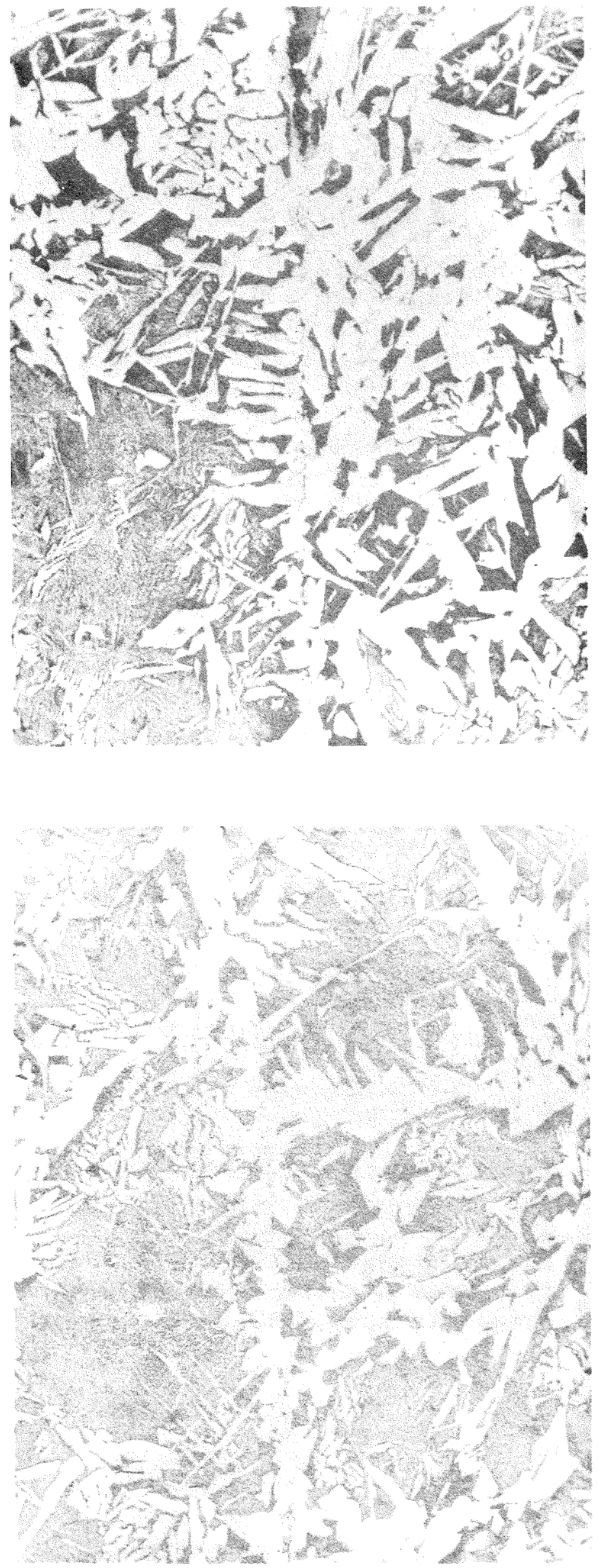

\section{Figure A6}

Micro of Sample A31 0.002 inches from surface showing oxide film at weld plane breaking up in ferrite band.
Figure A?

As for Figure 6 but at 0.008 inches from surface. 

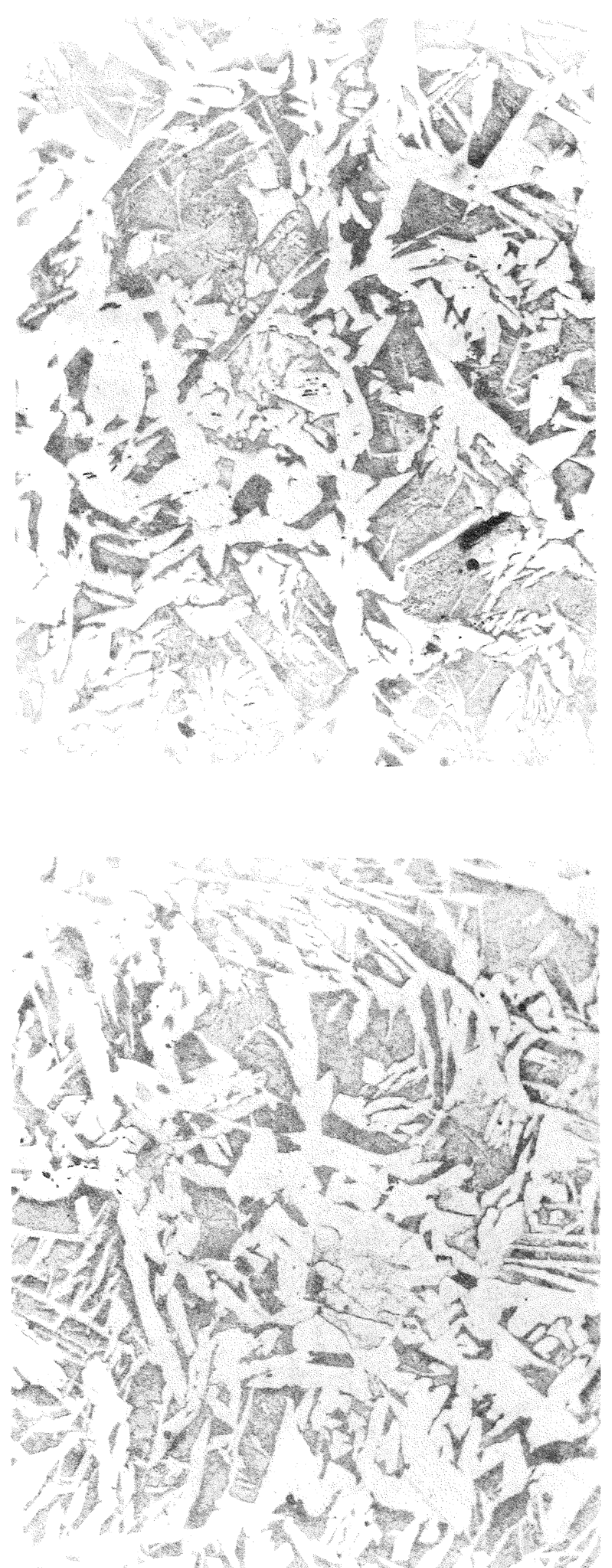

Figure A8

As for Figure 6 but at 0.024 inches from surface
Figure A9

As for Figure 6 but at 0.50 inches from surface and ferrite band no longer definable. 

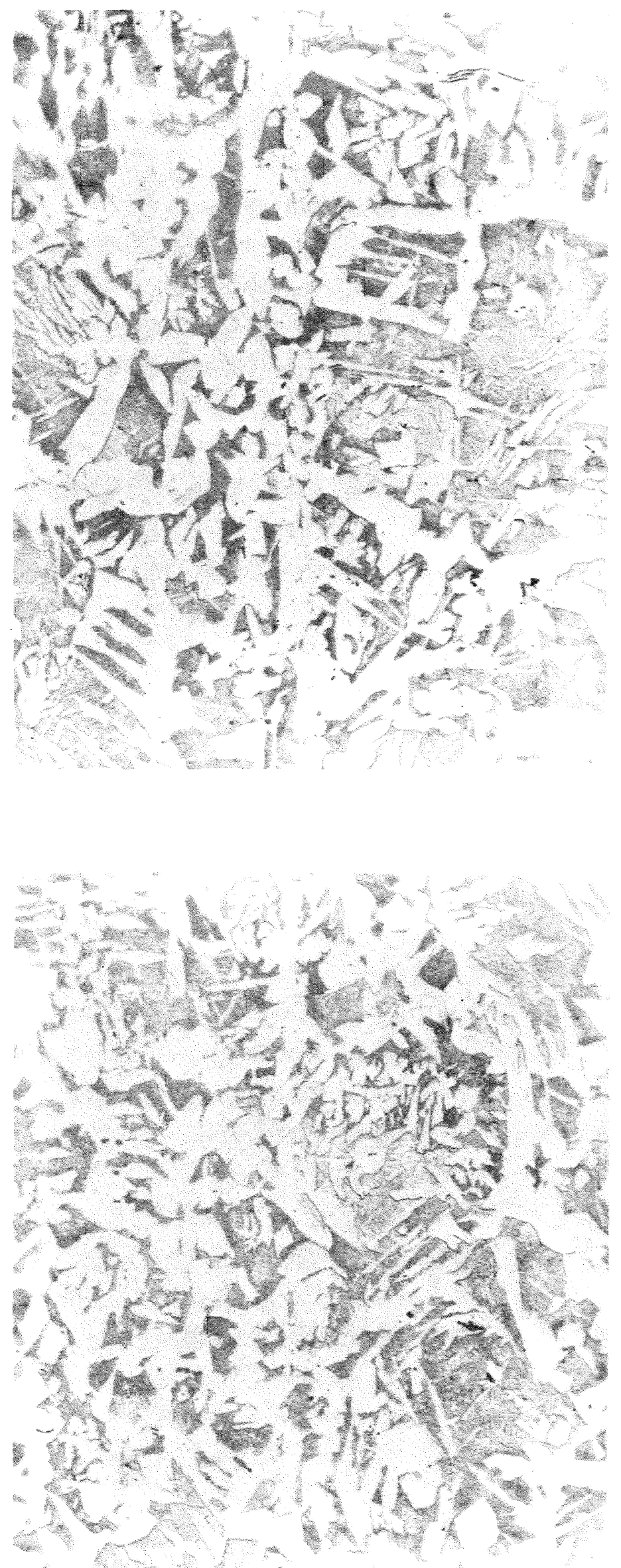

Figure A10

Micro of Sample A32 at 0.008 inches from surface showing fine line of oxide inclusions in a broken ferrite band.
Figure A11

As for Figure 10 but at 0.024 inche from surface and showing virtual disappearance of weld plane at this magnification. 